\title{
Reproductive Governance in a Fragile and Population-Dense Context: Family Planning Policies, Discourses, and Practices in Burundi
}

\author{
Joëlle Schwarz ${ }^{1,2,3}$ (D) René Manirakiza ${ }^{4}$ Sonja Merten ${ }^{1,2}$
}

Accepted: 21 October 2021 / Published online: 8 November 2021

(C) The Author(s) 2021

\begin{abstract}
This article describes the reproductive governance deployed in Burundi, which promotes fertility control through uptake of modern contraceptives as a solution to the economic hardship and land pressure of individuals and communities. Using a qualitative approach, we explore how women and couples in rural Burundi set their preferences, choices and practices of family planning, and how they relate with the government discourse. We describe how reproductive practices are complex and modulated by social and material factors and power dynamics. We argue that the current hegemonic discourse-largely supported by external donors-adopts a depoliticised and technocratic approach to family planning that aligns with neoliberal development frameworks, leaving existing power dynamics and resources distribution issues unexamined and unaddressed. By situating reproductive navigation in context, we show how medicalisation of reproduction is not fully enacted, and partly resisted by women and other actors.
\end{abstract}

Keywords Family planning · Burundi · Contraceptives · Demography · Reproductive health · Governance

Joëlle Schwarz

Joelle.schwarz@unisante.ch

René Manirakiza

manirakizarene2015@gmail.com

Sonja Merten

sonja.merten@swisstph.ch

1 Department of Epidemiology and Public Health, Swiss Tropical and Public Health Institute,

Socinstrasse 57, 4051 Basel, Switzerland

2 University of Basel, Basel, Switzerland

3 Department of Education, Research and Innovation, Center for Primary Care and Public Health (Unisanté), University of Lausanne, Rte de Berne 113, 1018 Lausanne, Switzerland

$4 \quad$ Université du Burundi, Boulevard Mwezi Gisabo, Bujumbura, Burundi 


\section{Résumé}

Cet article décrit la gouvernance reproductive au Burundi, qui prône le contrôle de la fécondité grâce à l'adoption de moyens contraceptifs modernes comme solution, pour les individus et les communautés, face aux difficultés économiques et à la pression foncière. En utilisant une approche qualitative, nous explorons la façon dont les femmes et les couples dans les milieux ruraux au Burundi définissent leurs préférences, leurs choix et leurs pratiques en matière de planification familiale, et comment elles et ils se positionnent par rapport au discours du gouvernement. Nous décrivons la complexité des pratiques reproductives et la façon dont elles sont modulées par des facteurs sociaux et matériels et par les dynamiques de pouvoir. Nous avançons que le discours prédominant actuel - largement soutenu par des bailleurs de financement externes - adopte une approche dépolitisée et technocratique de la planification familiale qui s'aligne sur les cadres de développement néolibéraux, laissant entièrement de côté les questions de dynamique de pouvoir et de distribution des ressources. En recontextualisant les parcours reproductifs, nous démontrons que la médicalisation de la reproduction n'est pas pleinement mise en œuvre, et qu'elle est en partie combattue par les femmes ainsi que d'autres acteurs.

\section{Introduction}

Since the 1994 International Conference on Population and Development (ICPD) held in Cairo, family planning (FP) has been promoted and supported by international institutions as a core development topic embedded in sexual and reproductive health (SRH). By ensuring women and couples universal access to SRH services including FP information and services that are to provide quality, accessible, affordable and safe modern contraceptives, two sustainable development goals (SDG) are targeted: ensuring healthy lives and promoting well-being for all at all ages (SDG3); and achieving gender equality and empowering all women and girls (SDC5). FP services for autonomous and empowering choices of women and couples are however implemented in settings that are not void of socioeconomic and political context. Scholars have indeed described how reproductive navigation is complex and influenced by social and material circumstances including local power dynamics (Bledsoe et al. 1998; van der Sijpt 2014), not aligning well with neoliberal development frameworks that pursue individual capacity building (Wilson 2015). Other scholars critically described how social reproductive topics such as FP or infertility have been placed into a biomedical framework, through a process of medicalisation (Busfield 2017). This paper describes the past and present deployment of FP policies, discourses and services in Burundi, and empirically explores how women's and couples' preferences, choices and practices in matters of reproduction are framed in context.

FP is widely promoted in Burundi, a post-conflict country that has a high population density (310 inhabitants per $\mathrm{km}^{2}$ ) and subsequent land pressure (République du Burundi 2016), and a high fertility rate (5.5) with a $23 \%$ utilisation rate of modern contraceptive methods (Ministère à la Présidence chargé de la Bonne Gouvernance et du Plan et al. 2017), characterised as a 'low demand' by the government 
(République du Burundi 2016). FP strategies and services are 'aggressively' (sic!) implemented throughout the country, supported by international donors (République du Burundi 2011b). Conducting research in Burundi, we observed how the government discourse is deployed throughout the country via diverse media, promoting the development argument that by using modern contraceptives, women and couples will enable lowering poverty and land conflicts for themselves and their communities. We further observed how the Catholic Church responds to this discourse by promoting alternative solutions and approaches targeting couples and focusing on social cohesion. Conducting in-depth interviews with women and other members of the community, we explored how these discourses were received and how they framed reproductive navigation. We found that preferences aligned with the government discourse, through a reported aspiration for reduced fertility, but they did not translate into uptake of modern contraception. Choices and practices were modulated by a web of social and material factors, including local power dynamics, showing a more complex reproductive navigation. Despite the relatively low demand for modern contraception, policies and programmes are continuously deployed and funded by external donors, strategically adapting approaches to reduce 'barriers to uptake', yet not addressing the social and material factors and power dynamics influencing women and couple's choices and practices. The empirical research enables discussing how the political discourse on FP in Burundi frames the socioeconomic and land issues as a technical problem (population density), for which it promotes a technical, medicalised solution (controlled fertility using modern contraceptives). We argue that the focus on FP as a depoliticised, technocratic and medical solution to the mentioned issues distracts from their political causes and hence, solutions (Ferguson 1994; Li 2007), leaving them unexamined and unaddressed. We finally discuss how technocratisation and medicalisation of FP are not fully enacted by actors, including health providers, religious leaders and potential users, hinting at resistances to the process.

The following two sections provide a brief historical background to FP policies and programming globally, and specifically in Burundi in light of the demographic, socioeconomic and political context. The empirical approach is then described, followed by the findings from our field research that describe and discuss how different actors relate to reproductive governance. The final section reflects on the processes of depoliticisation, technocratisation, and medicalisation of FP as a development programming in Burundi, highlighting the need of a nuanced, complex and situated approach to these concepts.

\section{Global Frameworks of Family Planning}

Contraceptive practices - the use of methods or devices to prevent conceptionhave a long history, from utilisation of abstinence, withdrawal, abortion and other barriersmethods used by many ancient societies. The modern era brought about a change whereby fertility control became a political stake 'involving many actors with radically different scripts' (Hartmann 2016, p. 89). In a context of industrialisation, Thomas Malthus (1766-1834) developed his theory on the need to control 
demography_of the poor, working class especially-linking preoccupations of economic development with those of population size, emphasising food supply and environmental capacity. After World War I, demography and population occupied attention on the political scene in the Northern hemisphere, throughout the political spectrum: socialists worried that working classes were too burdened by their large families to engage in social mobilisation; eugenicists promoted the need to limit the birth of unhealthy children for the development of nations; feminists called for a freedom in reproductive choices and emancipation; and anarchists created a libertarian current promoting sexual freedom and voluntary vasectomies to control births (Serna 2018; Lock and Nguyen 2018). In the Souths, reproduction was cast as a crucial site of debate and intervention by Northern powers (colonial and missionaries), in an attempt to control the issue of race (need of local manpower for resources extraction and exploitation) and sexuality (e.g. Africans portrayed as undisciplined and oversexualised) (Hunt 1999; Thomas 2003).

The invention of biomedical technology for birth control—-the pill—in the 1960's brought about radical societal transformations, as it provided women with the ability to control their fertility and sexuality. In the North, shaken by feminist and human rights movements, the pill was indeed received as a long-awaited innovation that supported the sexual liberation and women's emancipation, and that met a demand (Thomé 2016). In the Souths, the period was marked by independence and decolonisation movements, and the new development models to be designed and implemented. High fertility rates and population growth, promoted in colonies until then to ensure workforce, were quickly portrayed as major barriers to economic development (Ehrlich 1968; Meadows and Club of Rome 1982). Supported by international institutions, southern governments started promoting modern contraceptives as a technical solution to the identified 'population problem', not necessarily attuned with major concerns of communities and individuals. ${ }^{1}$ These discourses enabled the implementation of strategies such as the coercive sterilization programmes in India (Lock and Nguyen 2018).

The ICPD held in Cairo in 1994 marked a turning point on the topic of FP. Pushed by women's health groups, the ICPD reinscribed FP as a broader SRH concern, with the main objective to ensure bodily integrity and reproductive rights, instead of population control (Hardon 2006). It settled a definition of FP, still used today, that refers to people's rights to be informed about and to have access to methods for the voluntary regulation of fertility, to determine freely the number and spacing of children in the family. FP methods are generally divided into two groups: modern methods of contraception (e.g. hormonal contraception like the pill, injectables, implants; intrauterine devices (IUD); permanent methods of tubal ligation and vasectomy; or condoms, emergency pill); and natural methods of fertility regulation (e.g. lactational amenorrhea, symptom-thermal method, calendar or rhythm method, withdrawal). Governments draw FP policies and strategies to regulate the provision of contraceptive methods via FP services that are generally integrated into primary healthcare services. In such services, trained professionals are to provide

\footnotetext{
${ }^{1}$ In the pre-1990s era, FP in the Global South was often pursued through the use of the intra-uterine device (IUD), which gave more 'control' to doctors (see Takeshita 2012).
} 
information on available methods and support people making choices, ensuring that methods are appropriate to individuals' health and specific conditions. As highlighted by scholars, the notion of autonomy is limited by the 'medicalisation' process, whereby women are dependent on health providers to access medical contraception, for prescription and/or administration (Hardon and Moyer 2014).

Critical scholarships have highlighted how this shift in global discourse from a population control approach to reproductive rights was rather rhetoric than effective (Gautier 2002; Hodgson and Watkins 1997), and that FP initiatives in the Souths largely remained grounded in the theory established by Malthus: "Proposing birth reduction among the global poor as a solution to various global crisis phenomenafrom poverty, economic recession, migration and patriarchal systems to ecological destruction-and thus blaming the poor rather than, for instance, inequality, is typical of neo-Malthusianism" (Bendix and Schultz 2018, p. 260). In fact, as decried by Hartmann among others, the inverse discourse that a better distribution of resources (improvements in living standards) and power (improvements in the position of women) could bring about population change was seldom voiced or heard (Hartmann 2016). In post-ICPD development programming, FP has remained ambiguous as it is monitored and evaluated through population targets - such as modern contraceptive prevalence rate $(\mathrm{mCPR})$ and unmet need for contraception-that have been identified as contrary to the reproductive rights approach (Murphy 2010; Hendrixson 2018). Additionally, the discourse on women's empowerment through controlled fertility was criticised as aligning with neoliberal frameworks of development and poverty reduction that focus on individual capacity building, thus masking structural and power dynamics, and inequities (Wilson 2015; Potvin 2018). As demonstrated by scholars, the Western-inspired perception of universal human rights and individual autonomous choices does not fit well in practice, as reproductive behaviours are strongly modulated by local social contexts, power dynamics and contingent circumstances, including corporeal experiences, situated at the levels of family and communities (van der Sijpt 2014; Bledsoe et al. 1998; Cornwall 2007).

\section{Demography and Family Planning Policies in Burundi}

The history of reproductive governance in Burundi shows important fluctuations contingent on specific changing historical and demographic contexts. Demographers Thibon (2004) and Manirakiza (2008) describe a pre-colonial period where the authoritarian patrilineal family system and livelihoods organisation translated into a regulated fertility. Families were isolated into rugos, ${ }^{2}$ individual mobility was uncommon, children worked as domestic dependents and married at relatively late age (around 20). The combination of natural birth spacing through breastfeeding (children were weaned at around age two), high mortality and seasonal famines that caused reduced fertility explain the relatively low overall fertility rate. Colonisation brought diseases (mainly sexually transmitted infections) that increased mortality

\footnotetext{
2 There are no villages in rural Burundi, but rugos - the traditional family household entity-dispersed on the hills that group families around their patches of land.
} 
and infertility, and out-migration that changed the marriage patterns. In a second phase colons' and missionaries' health care, education and agricultural programmes led to a decreasing mortality. Agricultural intensification required workforce, leading to pro-natalist initiatives, such as the 'Belgian domestic training institutions for African women' that promoted short breastfeeding periods described by Hunt (1990). By the mid-1940's Burundi entered a demographic transition characterized by lower mortality and higher fertility. Fertility continued to increase after independence in 1962: agricultural cooperatives required larger workforce so women weaned their children early to join the labour force, and children represented production agents and family security (Manirakiza 2008). Between 1950 and 1975 the population doubled, triggering land issues and the rise of the 'overpopulation' discourse.

In 1983, in the global context of FP development programming supported by international donors, the government of Burundi established its Reproductive Health National Programme (PNSR). Fertility had reached a rate of 6.9 and modern contraceptive prevalence rate was $1.2 \%$ (Ministère de l'Intérieur and Institute for Resource Development 1988). In response to the government making FP a public policy and promoting the use of modern contraceptive methods, the Catholic Church-the predominant confession in Burundi ${ }^{3}$-implemented in 1989 its Action familiale (Family Action) that aimed to 'participate to the resolution of issues related to the galloping demography and AIDS, through means that are adapted to the Catholic Church's mission' (Caritas Burundi 2019, p. 7, our translation). Such means are natural family planning (NFP) for married couples that are promoted and taught during religious education sessions for couples.

Both initiatives were however suspended by the civil war that broke out in 1993 after the first democratically elected Hutu president was assassinated by the Tutsiled army, triggering massive violence between ethnic groups. ${ }^{4}$ In the next decade, the violence continued, causing, in addition to deaths and injuries, major internal and external population displacements ${ }^{5}$ and land grabbing on both sides (ICG 2003; van Leeuwen 2010). The 2000 Arusha Peace Agreements led to democratic elections in 2005 that put a former Hutu rebel in power. Hopes for political and socioeconomic stability however suffered as the political exercise predominantly consisted of securing power, dealing with political opponents and civil society activists. Socioeconomic reconstruction was secondary and largely left to international development and humanitarian actors.

\footnotetext{
$357 \%$ of Burundians self-report as Catholics, 34\% as Protestant (branch unspecified), 3\% as Muslim and 3\% as Adventists (Ministère à la Présidence chargé de la Bonne Gouvernance et du Plan et al., 2017).

4 Tutsi and Hutu are social groups that share the same language, culture, history and geography. While Hutus represent the majority, Tutsis, who were socially privileged under the monarchy and colonization, maintained their elite positions after independence. On the history of the ethnicization of the Burundian society, see Chrétien 1999. To be noted the different approaches, among scholars from different disciplines and perspectives, to explain the conflicts in the Great Lakes in the second half of the $\mathrm{XX}^{\text {th }}$ century: scholars like Chrétien or Thibon tend to highlight the weight of colonisation or history in general; while scholars like René Lemarchand tend to draw attention to the political context and logics of post-colonial actors.

5 Major population displacement (mostly Hutus) already occurred in 1972, after a surge of ethnic violence.
} 


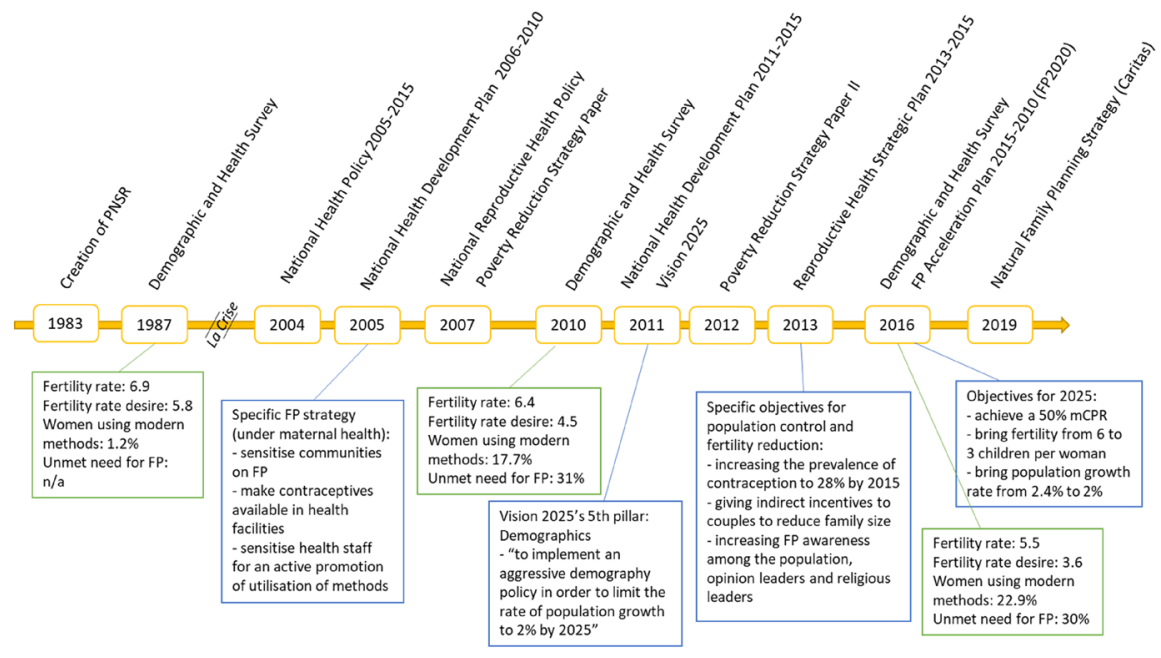

Fig. 1 Chronology of policies and strategies related to FP

Despite the (rhetoric) shift in FP discourse observed in most countries after the ICPD conference, FP policies and strategies emerging in the 2000s era in Burundi remained focused on merely population control. External donors re-invested in development strategies and supported the government in developing policies such as the National Health Policy or the Poverty Reduction Strategy Papers (PRSP) that set specific targets for population control, such as $\mathrm{mCPR}$, fertility rate and population growth rate. Based on these policies, Reproductive Health Strategic Plans were developed by the PNSR with UNFPA and bilateral development agencies, establishing implementation strategies to meet the set targets.

In 2010, religious leaders (Catholics, Protestants, Anglicans and Muslims) issued the Gitega Declaration that stated their 'engagement in supporting and contributing to the government's efforts to find solutions to the demographic challenge that are sustainable, efficacious, respectful of human rights and religious values' (Caritas Burundi 2019, p. 8, our translation). Thus, they aligned with the government discourse, but differed on solutions. Apart from Anglicans, religious authorities are strongly opposed to utilisation of modern contraceptives.

In 2011, Vision Burundi 2025-the 'planning instrument for development' supported by UNDP — sat the objective to 'implement an aggressive demographic policy in order to limit the rate of population growth to $2 \%$ by 2025 ' (République du Burundi 2011b). Across policies and strategies, target figures are continuously increasing (28\% mCPR by 2015 (2012) to 50\% mCPR by 2025 (2016)—see Fig. 1). To boost uptake of contraception, FP services are included in the performance-based 
funding (PBF) national scheme supported by external donors. ${ }^{6}$ The financial scheme in place during our fieldwork incentivised health facilities according to the quantity of pills and injections delivered (5000 $\left.\mathrm{BIF}^{7}\right)$ or implants and IUDs inserted $(14,000$ $\mathrm{BIF})$; and incentivised hospitals for vasectomy or tubal ligation (60.000 BIF) (République du Burundi 2014). In its commitment to the global initative FP2020, ${ }^{8}$ the government planned to increase its budget allocation for FP, and thereby called for support by external donors. In 2015, 1.56 million USD were allocated to FP activities, of which domestic resources accounted for $2 \%$. Of the four main health programmes of the Ministry of Health, the PNSR was allocated $27 \%$ of government funding, and $32 \%$ of donor funding in 2015 , thus being the second mostly funded programme after HIV (The World Bank and UNICEF 2017).

Of the 735 health centres in Burundi, 14\% are faith-based and have a convention with the Ministry to implement the minimum activities package (République du Burundi 2011a). They run as public clinics, except for FP where only natural methods are promoted and counselled. To ensure FP services coverage, the PNSR has established dispensaries near the faith-based clinics where modern methods are provided.

More generally, the political, economic and social situation of the country has remained very fragile since the Peace Agreements. The vast majority of rural populations lives off subsistence agriculture and there are very limited economic alternatives as neither industry nor tertiary economy is developed (Uvin 2009). In 2008, it was estimated that $42 \%$ of households lived below the subsistence level of 0.25 hectares (World Food Program 2008). The return of refugees has led to increased land pressure and conflicts. The controversial National Commission on Land and other Goods (CNTB) put in place in 2006 tend to add fuel to the existing ethnic tensions as its partiality is questioned (Purdeková 2017). Additionally, the inheritance system (all male children inherit an equal share of the land), deregulated land markets, and a weak land registry system have transformed the Burundian hills into a 'patchwork of continuously diminishing familial land holdings' (Vervisch et al. 2013). Land pressure and conflict has exacerbated tensions between the different concomitant mediation and justice mechanisms, such as the CNTB, the traditional bashingantahe institution 9 and the formal hill councils installed by the government in the 2005 reforms (Ingelaere and Kohlhagen 2012; Wittig 2017). In 2009, three quarters of the cases treated in court were related to land conflict (Kohlhagen 2012). Some conflicts were related to returnees claiming back their land, while other conflicts included family disputes between siblings or parents in heritage. Recent initiatives that aimed

\footnotetext{
6 Targeting broader primary health care indicators, PBF is managed by the health ministry, with technical and financial support from USAID, the World Bank, the European Commission, Belgian Technical Cooperation, and GAVI, as well as NGOs such as CORDAID, Healthnet TPO and Gruppo Volontariato Civile.

7 Circa 3.2 USD in December 2014.

${ }^{8}$ FP2020 invites governments to make political and financial commitments for FP, and with which multilateral organisations and partnerships, private industry and civil society organisations and foundations are invited to align.

9 Bashingantahe was a pre-colonial institution of customary 'notables' that ensured sociopolitical order and conflict resolution. It still exists today but 'shares' its role with formal justice institutions.
} 
at reconfiguring space and social relations-including peace villages, IDP site clearances and land sharing - were mostly unsuccessful, as targeted beneficiaries decried a lack of access to basic services, or lack of security (Purdeková 2017; Falisse and Niyonkuru 2015).

\section{Empirical Approach}

The study is based on field research conducted in two rural areas in Burundi between 2013 and 2016. We explored individual and community perceptions and responses to the discourse on the need to have fewer children, in the provinces of Karusi and Rutana, using qualitative methods. Data include field notes from observations over a cumulated period of 9 months (in health facilities, community centres, schools, churches and everyday interactions); narratives from in-depth interviews with rural women and men of reproductive age we followed over the research period $(n=16)$; transcripts and notes from formal interviews and informal discussions with key informants (Catholic and Anglican priests, health providers, community leaders, peer educators, teachers, PNSR agents) $(n=8)$; and transcripts from focus-group discussions conducted with peer educators, community health workers $(\mathrm{CHW})$ and young people $(n=40)$. Interviews were conducted in Kirundi and French with the support of Burundian (female and male) research assistants for translation. For this study, we specifically searched our data (field notes and interview transcripts) for entries on media activities on FP, and we conducted a (non-systematic) search for articles on FP on the websites of existing press in French. ${ }^{10}$ Transcripts and field notes were analysed using a grounded theory approach (Charmaz 2006). ${ }^{11}$

To set the background presented above, we conducted a desk review of policy documents from the PNSR and other institutions in the field of reproduction. We collected and analysed policy documents such as the National Health Policies, National Demographic Policies, National Reproductive Health Policies and Strategic Plans, and studies conducted by the PNSR over a period spanning from 1988 to 2019.

\section{Findings and Discussion}

\section{A Hegemonic Discourse on 'Overpopulation’}

Conducting fieldwork in rural Burundi, we observed that throughout the country, giant billboards sponsored by the PNSR and a European cooperation agency were displayed in the streets, promoting FP. Some had representations of households with numerous sad-looking children and worried parents who said 'How will I get rid of these problems?', with a message reading 'If we hadn't had so many children, we wouldn't have the problems we have today' (Image 1). Others portrayed scenes

${ }^{10}$ Iwacu, Yaga Burundi and Radio Isanganiro.

${ }^{11}$ For more details on the methodology, see Schwarz et al. (2018). 


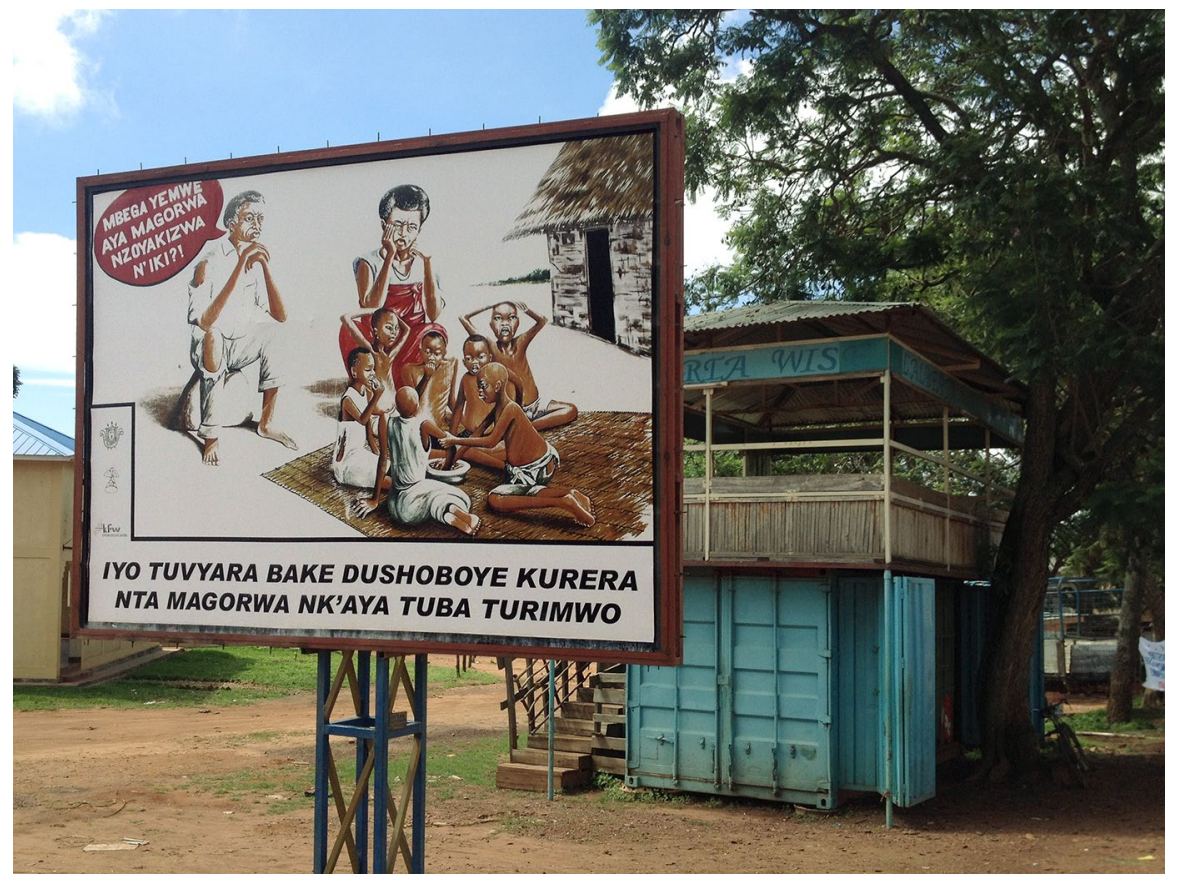

Image 1 FP promotion billboard 'If we hadn't had so many children, we wouldn't have the problems we have today' (Photo: J. Schwarz)

of land partition with numerous people present on a small piece of land, with the message: 'land has become scarce, let's have fewer children, so we won't leave family conflicts behind' (Image 2). In administration buildings and health facilities, we regularly found posters promoting the same message: large families cause poverty and land conflicts. We also found that a radio soap opera, Agashi (Hey! look again!), which was much listened to by rural populations, addressed the topics of FP, sexual and reproductive health and HIV/AIDS. Broadcasted twice a week on seven radio stations in Kirundi with national coverage the Agashi programme was sponsored by external donors (Population Media Center 2018).

In our research sites, the PNSR acted through a European-funded SRH programme to promote contraceptive methods and create demand in the community. Health centres were equipped with televisions displaying films on $\mathrm{SRH}-$ mostly about prevention of HIV and adolescent pregnancies and on FP promotion-in the facilities' waiting space. In addition, community activities were set up to boost demand for FP. CHW and peer educators were locally trained on SRH to create a link between health providers and the population, and were equipped with an image box and a booklet to support these sensitization activities. The message here was similar: having fewer children allows alleviating poverty and conflicts (Image 3).

Trained and financially incentivized for the distribution of modern contraceptives, health providers were the holders of the medical knowledge on these technologies, and the gate keepers for access. We found that the offer for contraceptives 


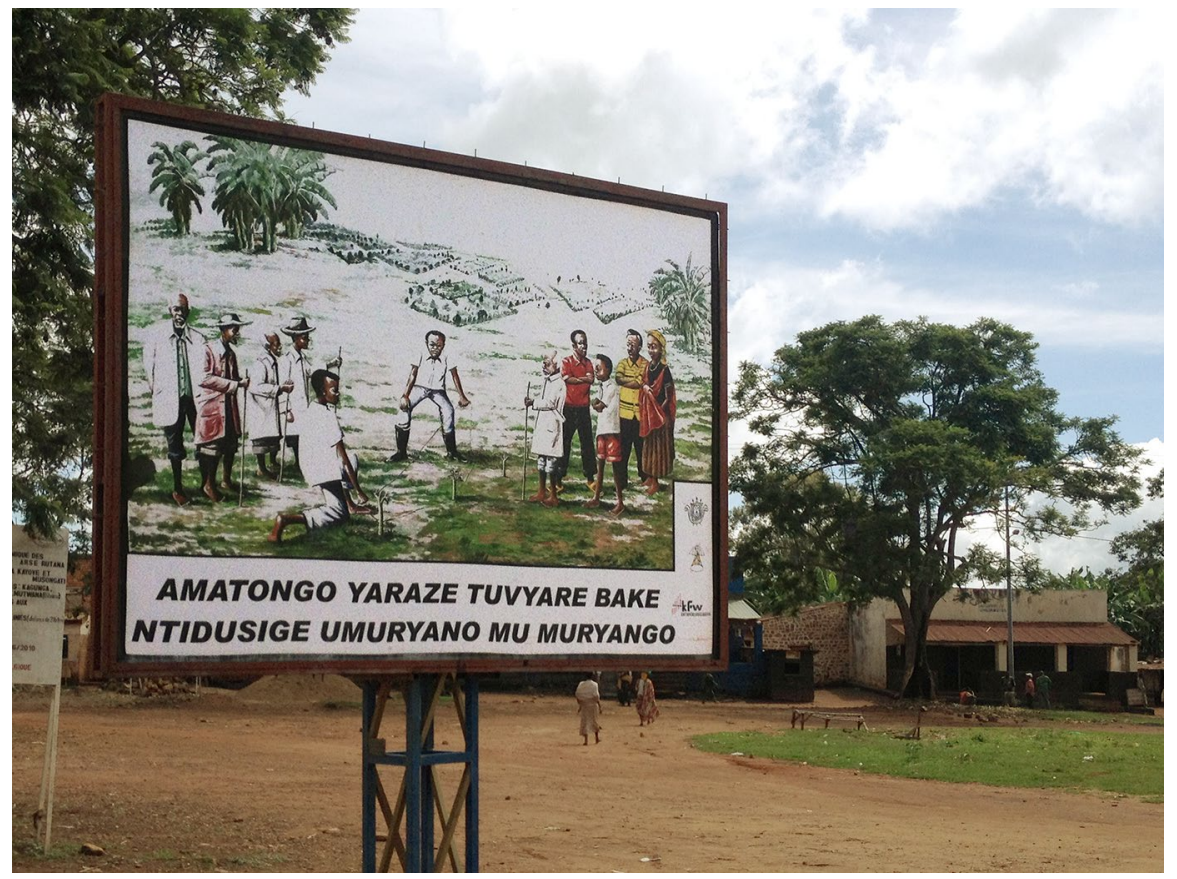

Image 2 FP promotion billboard: 'land has become scarce, let's have fewer children, so we won't leave family conflicts behind' (Photo: J. Schwarz )

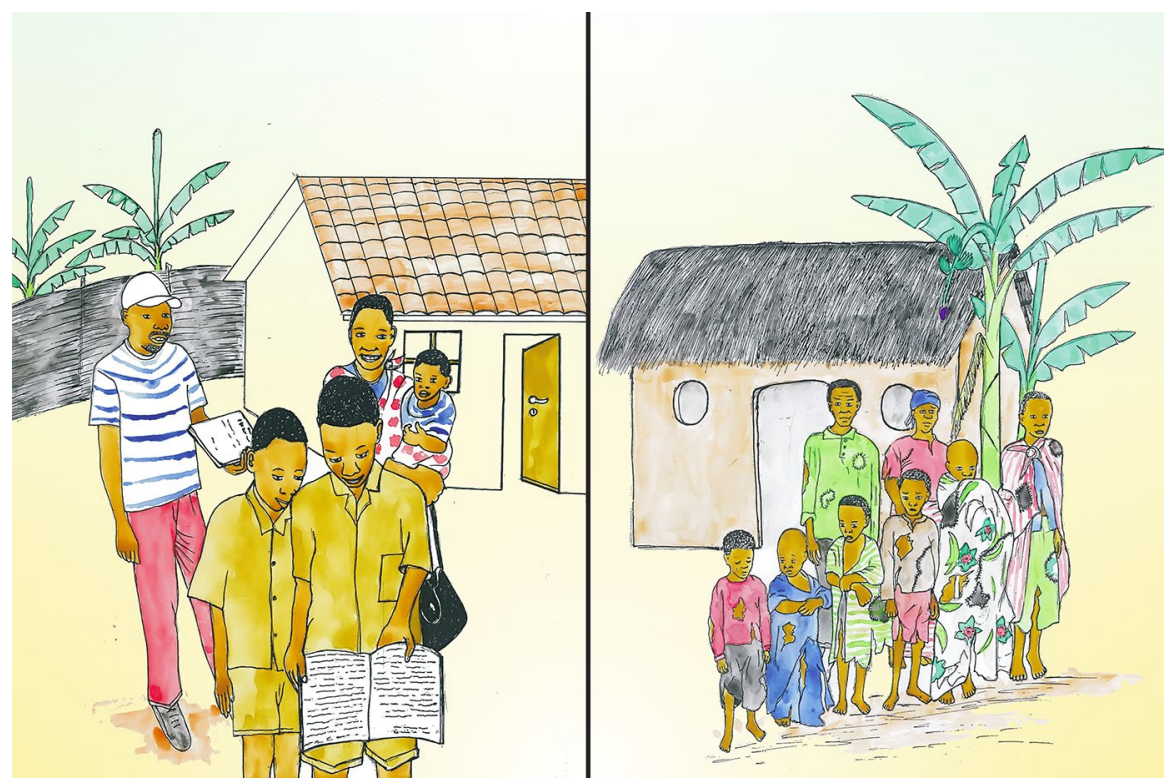

Image 3 Image box used by $\mathrm{CHW}$ and peer educators for FP community sensitization (Ministère de la santé publique et de la lutte contre le SIDA, PNSR, CORDAID, IADH, CPAJ, SWAA-Burundi)

吂 
was limited: mostly injectables were promoted, shortages were not uncommon, and we were told that non-married women were sometimes refused FP methods. Counselling quality was low because, as we observed, it was usually offered in groups during vaccination in health facilities, leaving little to no room for individual counselling. We found that health providers adopted different attitudes with regards to FP. Some complained about the 'lack of education' and 'irresponsible behaviour' of rural populations that explained the low demand for modern contraceptives, according to them. Others acknowledged women's concerns and issues in relation to contraceptives, such as a nurse who explained that frequent contraceptives' side-effects - mostly bleeding — were indeed a serious concern for rural women. He invested time for individual counselling and offered free-of-charge treatment in case of side-effects. ${ }^{12} \mathrm{He}$ had adopted the lay discourse that we often heard in interviews and discussions: 'all bodies are different and all methods are not suited for all bodies'. He considered that users needed to find their appropriate method, while acknowledging the limited choice of available contraceptives. Some health professionals were ambiguous about the scientific evidence, such as a Pentecostal medical doctor working for an NGO promoting FP, who expressed his concerns about hormonal contraceptives, namely the unknown long-term effects on fertility and health, such as cancer. He added he wouldn't want his wife using such products.

CHW from our research sites were trained to sensitise the community on FP, namely modern contraceptives, through an NGO programme. In focus-group discussions, CHW explained that their position was complex as they were at the nexus between the government's and the church's positions on acceptable methods for birth control. As members of the community including social and religious belonging, their role was sometimes difficult to sustain, and several CHW reported they were threatened of excommunication by the Catholic Church unless they stopped their activities. At the same time, they were also at the nexus between the medical and the lay knowledge on contraceptive technologies. The issue of side-effects was largely debated in the community, a topic that medical authorities mostly disregarded and treated as 'erroneous rumours', 'beliefs', and 'barriers to uptake'. CHW complained that their short training and limited acquired medical knowledge was insufficient to address the concerns and questions from the community, thus hampering their credibility and social status acquired through their activities.

Based on the Gitega declaration of 2010, the Catholic Church had aligned to the government discourse on the need to control demography, and the agreement was for public health facilities to promote and provide modern contraceptives, and for faith-based facilities and Action familiale to promote NFP, in a distinct but collaborative way. In reality, we observed that it is a competition of values, knowledge and strategies that took place, as illustrated in this newspaper interview of the PNSR head:

If nothing is done, Burundi won't be able to survive the demographic pressure. ... Priests promote utilisation of natural methods, but they don't know much. They should let us do our work (Nkurunziza 2011: our translation).

$\overline{12}$ The PBF system did not include reimbursement of treatment of side effects. 
Through their activities, the Catholic Church not only promoted NFP as an alternative to the government's methods, but it also included a discourse on social cohesion and communication in couples required for practicing NFP. The discourse promoted is based on a call for a 'responsible parenthood': an individual code of conduct that allows a responsible management of fertility, through 'the knowledge and respect of biological functions; a mastering of reason and will on the instinct and passion tendencies; a thoughtful and generous determination to grow or not grow a large family, to avoid temporarily or for an undetermined time a new birth; a considering of the moral order, as established by God and of which the conscience is the faithful interpret' (Caritas Burundi 2019, p. 6, our translation). Exploring these aspects of moral order and values for reproductive responsibility with participants, we found that the Church promoted the moral and social values of natural methods: moral because disciplined sexual behaviour is perceived as virtuous; and social because these methods require continuous communication and shared responsibility, hence beneficial to couple cohesion. In the post-conflict fragile context, the consequences of social changes and disorders in the family institution - a central pillar in religion-are of great concern to religious leaders who try to accompany and support communities in preserving family values and norms. All religious leaders we interviewed were concerned by phenomena such as cohabitation without a religious ceremony-15\% of women reported living with their partner unmarried (Ministère à la Présidence chargé de la Bonne Gouvernance et du Plan et al. 2017)_, gender-based violence, HIV, and land conflicts. In this frame, FP was often considered as an opportunity for family and couple relations counselling. In fact, educational and counselling sessions for couples organized by the parishes in our research sites made both partners attendance mandatory.

Locally, many activities of the Catholic Church around FP were focused on opposition to the activities of the PNSR. A Catholic priest explained in an interview that he perceived modern contraception as a 'dangerous easy way out of responsibilities' that is detrimental to family values. His rationale was that in a context of strong gender inequality visible through domestic violence and limited rights of women, modern methods worsened women's position, as they allow husbands to 'irresponsibly dispose of their wife's bodies without fearing consequences [i.e. pregnancies]'. An Abbot explained how he saw an issue with the government incentivizing FP services in a context of widespread poverty, including among health providers. He hinted at providers' financial and moral corruption, over-prescription of contraceptives and silence over contraindications and side effects of products. He felt his role was to inform about negative effects on bodies and fertility. Some religious leaders did so during mass and couples education sessions. Participants reported indeed that during mass it was announced that women using contraceptives were not allowed to take the host, as they were 'killing the unborn'.

\section{A Discourse that Shapes Reproductive Preferences}

When asked about family size preference, participants had two standardized responses: 'I wish to have the number of children that we can raise' or 'I will have 
the number of children that God will give me'. The first exactly echoed the government's discourse, whereby the number of children should be adapted to households' resources. The second was spontaneously given out as such by some participants, but usually further nuanced during interviews with a 'With God's help, I will have the number of children that we can raise'. Trying to go beyond the formatted responses, we explored personal and contextual reasons participants gave to their reported preference, and their actual practices. We mostly use the narratives from three women - Clémentine, Florence and Christine — to illustrate different reproductive trajectories.

We found that participants systematically associated their family size preference with their household land situation, as well as to the political and economic instability and uncertainty. Discourse on having a number of children scaled on land ownership and productivity was held by the vast majority of participants, regardless of their utilisation of methods for birth control. For example, Clémentine, a mother of three children who struggled to ensure the livelihoods of her family, with little support from her husband who suffered from alcoholism, explained how she questioned the perception that three children are few, considering her financial and land limitations:

Clémentine: If I look at the land we exploit, it's not fertile unless we buy fertilisers, and money is difficult. ... I don't want to space my births, I want to stop all-together. [...] We have a small plot of land that doesn't produce much anymore. Also, are three children really few? If God keeps them as they are... I think it's enough.

[Married woman aged 35, 3 children, not using FP method (Butare, 2014)]

Clémentine had never used any FP method but instead had difficulty in getting pregnant, and her third pregnancy — a son—came as a blessing she explained when we first met her. Two years later, she was more concerned about fertility control because her son was 2 years old and she didn't have a plan for achieving her goal to stop childbearing. Although her husband had agreed for her to use modern methods she feared them because her 'body is tortured by poverty and malaria'; and while she had been taught about natural methods in the past, she didn't trust much these methods because 'pregnancy occurs by chance' she said. She also explained negotiating sexual abstinence with her husband was difficult because he was often drunk. Her desire to limit her family size to three children was strongly related to her precarious situation marked by agricultural work hardship, uncertainty about food security and the related consequences on her fragile health, and her husband's dependency.

Florence, a woman of the same age, explained that after her first birth she tried the injections that were promoted to her at delivery, and as she experienced no negative effects she continued and successfully spaced her three births by five years each. She explained her rationale as follows:

Florence: I decided to use injections because I wanted few children and I wanted them to be spaced, because nowadays it's difficult if you have many children. 
Joëlle: Traditionally, Burundians like large families, why did you choose to have few children?

F: Because our means are limited, and the land on which I can raise my children is limited. ... If I had many I wouldn't be able to feed them.

[Married woman aged 32, 3 children, using injections (Rutana, 2014)]

Florence lived on a plot of land away from the rugo, hence away from her in-laws. She explained how she suffered when she was a child as her parents had died young and she suffered from malnutrition. She linked her desire for having fewer children to their poor situation marked by small land ownership and uncertainty around its yield. She explained a desire to secure a better future for her children, different from her upbringing conditions.

The discourse of having fewer children scaled on households' resources was also displayed by young women, and some participants like Christine below, despite being opposed to modern methods of contraception, advocated for reduced fertility among her friends and neighbours:

Christine: As far as I'm concerned, I consider the means where I live. I couldn't sustain having many children because our means are limited. I would advise people to have the number of children they can raise, and also to sensitise others, because land is deteriorating, it's not easy to get enough to eat these days.

[Woman aged 18, lives with her partner unmarried, 1 child, using calendar method (Karusi, 2016)]

The quote from Christine go in the direction of an individual responsibility to scale the number of children on one's own means to ensure livelihoods and economic situation, and she further suggests that the message is to be promoted in the community, for a shared application of individual responsibility.

Despite the widely shared discourse on the need to have fewer children to palliate the common situations of limited land and yield and low economic resources, people adopted different strategies with regards to FP that appeared contingent on other factors. We now explore these factors.

\section{Contingent Circumstances that Modulate Reproductive Choices and Practices}

We found that decision on utilisation of FP methods for birth spacing or limiting in our participants was contingent on the existence and the role of the extended family and kin. Mother-in-laws seemed to play an important role and influence on reproductive decisions and practices of rural women. Christine came from a disrupted family; she now lived with her partner unmarried in another province and her mother-in-law, who lived nearby, had a large influence on her couple's reproductive decisions and methods. She taught Christine how to monitor her menstrual cycle to observe her fertility periods to avoid pregnancy. Inversely, Florence who also came from a disrupted family married a man who moved out of the family rugo to establish a new independent household. She explained how she and her husband together discuss their economic situation and capacity to raise 
children within their limited resources (to cover food, health and school costs), without the influence of neither his nor her kin:

We discussed with my husband, and he agreed that according to his preferences, we should stop with three children, because it has become more difficult to feed the three recently, so to avoid putting a heavier burden on our home. ... We talk about all these things in bed, or elsewhere, as long as it's only the two of us. [Rutana, 2016]

Family structure, including the presence of in-laws, had an influence on the gender-dynamics within couples. Florence explained how she actively and fully took part in the management of her households, including financial aspects. This was quite exceptional and not found in most other households we followed, where men only were in charge of finances-managing expenditures related to fertilizers and seeds, school, health and social events - and where they are responsible of the family size decisions. In interviews, participants who practiced NFP expressed pride in the fact that partners had to collaborate for a disciplined behaviourobserving abstinence periods - to successfully plan their families. Inversely, as men rarely visit a health facility unless ill or injured, women went alone to health providers for information, counselling and provision of modern contraceptives, shifting responsibility for FP practices. This responsibility and autonomy was assessed by many participants as risky. Florence for example expressed that even if she was able to control her fertility using injections, she was not protected from the risk of her husband having children outside of marriage, and bringing them into their household, adding burden to their subsistence means.

Our longitudinal research showed that FP practices were also contingent on life events and situations. One participant—a 28 years old teacher-had his wife use injections to prevent a pregnancy as she had not finished her secondary school due to a first unplanned pregnancy that led them to marriage. Despite expressing moral values against modern contraceptives and his wife complaining about the effects of injections on her body, his strategy was to use injections until she finished school, when they would switch to natural methods. He explained that natural methods are difficult to apply, but as they are educated they could succeed to achieve their preferred number of children, which, as he explained would be planned based on their financial means:

Considering the times we're living, I will pray to God that he gives us the number of children that we can raise. ... If God gives me 10 children today, I won't be able to raise them. But little by little, we'll have the means, so we'll be able to raise them. The chiefs of today won't be the chiefs of tomorrow (uko bukeye siko bwira). Today you may have the means, but tomorrow you may no longer have them. If things don't go well, we can decide to have 2 or 3 children. (Karusi 2014)

This narrative illustrates that having numerous children was still associated with wealth, but could soon shift to being a liability. Behind the government's discourse of 'having the number of children one can raise' lays indeed a secondary 
message that suggests that wealthier people are allowed more children and poorer people should restrain. And this was sometimes perceived as unfair, expressed by a few people who complained that 'those who tell us to have fewer children are not showing the example' referring to health providers and community leaders. Wealth was considered as volatile. Many families lost their assets-land and cattle-during the conflict phases, and wealth was mostly acquired through government positions and acquaintances, hence dependent on the political situation. Thus, many considered that the future was very uncertain in the current context, even for people with an improved position like the teacher above, rendering the notion of planning difficult. The theme of uncertainty emerged frequently in our data. In fact, most of the narratives showed that individuals and couples conjugated with uncertainty to plan their families, as anything else in life.

Last, choices of FP methods were contingent on bodily realities. As taught in school and in church, practicing NFP required a regular menstrual cycle, and thus were not suited for all women. We found many participants had excluded the option of NFP because of their irregular cycles. Using modern contraception could lead to physical side effects that unpredictably occurred in some women but not in others. Physical side effects were assessed as problematic by participants because they are unpredictable, and because they affected women's everyday life, their capacity to work for instance. As presented elsewhere (Schwarz et al 2018), in a context of widespread malnutrition and anaemia, where women bear just about all the agricultural work, excessive irregular bleeding is problematic and a good reason not to use modern methods.

\section{Concluding Remarks}

This research has shown how the complex historical and political context of Burundi has led to the maintenance of a hegemonic FP discourse on 'overpopulation' since the 1980's, distant from autonomous choices and empowering practices. Most actors in the country aligned with the neo-Malthusian stance that 'overpopulation' is a barrier to socioeconomic development and a source of land conflicts. The failure in shifting from population control to sexual and reproductive health and rights prevents constructive understanding and action on individuals' and couples' FP rationales and practices: 'instead of clarifying our understanding of these [reproductive] issues, it obfuscates our vision and limits our ability to see the real problems and find workable solutions. Worst of all, it breeds racism and turns women's bodies into a political battlefield' (Hartmann 2016, p. 4). Our research however shows that, in Burundi, despite a relatively low adherence to modern contraceptives, the government technocratic apparatus for FP_lead by the PNSR but largely supported by external donors-seems to serve a double purpose: first it rhetorically depoliticises the failures of the State in ensuring socioeconomic development and alleviating land pressure issues by situating responsibility at the individual and couples' level; and second it enables the government providing a simple, technical solution (modern 
contraceptives) to the identified problem (fertility), with full support from external donors and contraceptive products providers ${ }^{13}$.

In substance, by aligning with FP development frameworks and initiatives such as FP2020, the reproductive governance in Burundi follows a technocratisation process, by which the socioeconomic and land issues are presented as a set of technical problems requiring technical expertise and solutions, rather than as a series of complex political problems that require examining and addressing global and local power dynamics and systemic solutions (Ferguson 1994; Li 2007; Potvin 2018). Technocratisation thus enables a depoliticisation of the serious, yet sensitive and conflict-prone issues of failed management of land tenure, economic hardship and gender inequality in access to land and livelihoods that, we argue, partly explain the relatively low demand for FP. Such global and local discourse on FP eludes evidence that have shown that improvements in living standards and the position of women, via more equitable social and economic development, are the best way to motivate people to want fewer children' (Hartmann 2016, p. XXX). However, it enables maintaining particular political systems and power structures in place.

Our empirical research has also shown that framing FP as a technical, medicalised solution that women and couple simply need to be informed about and uptake does not reflect situated, contingent embodied realities. Medicalisation has been used to describe the processes by which technologies increasingly govern populations through medical control, and exerting social control (Busfield 2017). We have highlighted how FP medical technologies can aim to discipline social reproductive behaviour (through the government discourse), but they can also be resisted (low demand in rural Burundian women). We thus align with Hardon and Moyer's call for ' studies of medicalization [that are] sensitive to the site and technology-specific micro-dynamics of power, the specificities of local markets in which medical technologies generate value, changes in power dynamics and markets over time, and the social relations in which technologies figure." (2014, p. 111). Reproductive navigation in Burundi proved more complex, contingent on social and material circumstances, and framed by power dynamics such as gender and generational relations. Interestingly, while the Church resisted to enact a medicalisation of FP by opposing modern contraceptives, their alternative solution that aimed at embracing social dynamics adopted a medicalised approach: limiting their teachings to women who have a standardised reproductive body with regular menstrual cycles produces the effect of excluding many women. The inability to consider the diversity of bodily realities can be interpreted as a sign of medicalisation of reproductive health, whereby biomedical, standardised knowledge on fertility and menstrual cycles has taken over other forms of knowledge. ${ }^{14}$

Our research has shown that the depoliticisation, individualisation and medicalisation processes are however not enacted by all actors. By embedding its FP discourse in the social field-instead of the medical field-the Catholic Church offered

\footnotetext{
13 On the role of pharmaceutical industries providing products for FP programmes in low and middleincome countries, see Bendix and Schultz (2018).

14 e.g. the role of traditional birth attendants and their knowledge have quasi disappeared in Burundi, as an effect of incentivising institutional deliveries through performance-based financing.
} 
a solution closer to the concerns of populations. In post-conflict Burundi where disruptions of family structures and social fabric affect many households (Uvin 2009), we found that the approach and services offered by the Church were appealing to rural women and couples, as they served the primary purpose of mediating social disorder and uncertainty. They are however limited in access, as we have described. Some health providers did not fully endorse the medicalisation discourse because of the discrepancy they observed in their clinical work between women's bodily experiences (side effects or irregular cycles) and the medical discourse that dismissed these issues. This discrepancy has been described as a social distance by Richey who observed the same phenomenon in Tanzania: 'FP service providers are marked or identified at the clinic level by their knowledge of modern methods. These technologies are designed for bodies that are the same, but when they are implemented in the real-world context, bodies are different. Service providers are then in the difficult position of negotiating between the needs of the different bodies and the expectations of the family planning apparatus' (2004, p. 68).

Finally, we found that the individual responsibility to control fertility, as promoted by the government, was not endorsed by many women, who reported preferring natural methods and shared responsibility. We interpret that the endorsement of a reproductive responsibility by women, in a context where gender inequities place them in fragile and dependent configurations, is not desired, even contested. Natural methods appear more desirable perhaps also because they encourage a positive form of masculinity - through positive self-control - that is precisely challenged in post-conflict times (Sommers 2013; Daley 2007; Berckmoes and White 2014). We interpret the relatively low adoption of modern contraceptives not as a rejection of FP altogether, but rather as a resistance to the technical solution proposed that is in inadequacy with the social and material circumstances and power dynamics that frame women and couples' everyday life. We thus argue that the hegemonic FP discourse and solution promoted by the Burundian State are partly challenged in adoption because they are distant from local realities, knowledge, concerns and embodied social needs.

Acknowledgements We are most grateful to the women and men in Burundi who gave us time and trust to share their stories and experiences. We thank our qualitative research assistants, Marie Souavis Ndorere and Gaston Uwimana, as well as Fiona and Evelyne for their support; to the SwissTPH teams in Bujumbura and Basel and CORDAID team staff in Bujumbura and The Hague for their essential support of research activities; and to the PNSR in Bujumbura for sharing their documents and experiences. JS is obliged to the Dutch Ministry of Foreign Affairs, The Swiss Tropical and Public Health Institute, and the Swiss School of Public Health PhD Programme (SSPH+) for their financial support during her doctoral research. We thank Jean-Benoît Falisse and Béatrice Bertho for their comments on a first version of this paper. We are grateful to the two anonymous reviewers for their insightful comments and suggestions.

Funding Open access funding provided by University of Basel. Funding was provided by Ministerie van Buitenlandse Zaken (Grant Number 24912).

\section{Declarations}

Conflict of interest On behalf of all authors, the corresponding author states that there is no conflict of interest. 
Open Access This article is licensed under a Creative Commons Attribution 4.0 International License, which permits use, sharing, adaptation, distribution and reproduction in any medium or format, as long as you give appropriate credit to the original author(s) and the source, provide a link to the Creative Commons licence, and indicate if changes were made. The images or other third party material in this article are included in the article's Creative Commons licence, unless indicated otherwise in a credit line to the material. If material is not included in the article's Creative Commons licence and your intended use is not permitted by statutory regulation or exceeds the permitted use, you will need to obtain permission directly from the copyright holder. To view a copy of this licence, visit http://creativecommons.org/licen ses/by/4.0/.

\section{References}

Bendix, D., and S. Schultz. 2018. The political economy of family planning: Population dynamics and contraceptive markets. Development and Change 49: 259-285.

Berckmoes, L., and B. White. 2014. Youth, farming and precarity in rural Burundi. European Journal of Development Research 26: 190-203.

Bledsoe, C., F. Banja, and A.G. Hill. 1998. Reproductive mishaps and western contraception: An African challenge to fertility theory. Population and Development Review 24: 15-57.

Busfield, J. 2017. The concept of medicalisation reassessed. Sociology of Health \& Illness 39: 759-774.

Caritas Burundi. 2019. Stratégie d'introduction des services de planification familiale naturelle dans les formations sanitaires de l'Eglise catholique au Burundi. Ensemble pour la paternité et la maternité responsables. Bujumbura: Caritas Burundi.

Charmaz, K. 2006. Constructing grounded theory: A practical guide through qualitative analysis. 208.

Chrétien J.-P. 1999. Hutu et Tutsi au Rwanda et au Burundi. In Au coeur de l'ethnie. Ethnies, tribalisme et Etat en Afrique., ed. J.-L. Amselle, E. M’Bokolo, 129-165. Paris: Le Découverte

Cornwall, A. 2007. Taking chances, making choices: The tactical dimensions of "reproductive strategies" in Southwestern Nigeria. Medical Anthropology 26: 229-254.

Daley P. 2007. Gender \& genocide in Burundi. The search for spaces of peace in the Great Lakes region, Bloomington, IN: Indiana University Press.

Ehrlich, P.R. 1968. The population bomb. New York: Ballantine Books.

Falisse, J.-B., and R.C. Niyonkuru. 2015. Social engineering for reintegration: Peace villages for the 'uprooted' returnees in Burundi. Journal of Refugee Studies 28: 388-411.

Ferguson J. 1994. The anti-politics machine. Development, depoliticization, and bureaucratic power in Lesotho: University of Minnesota Press.

Gautier A. 2002. Les politiques de planification familiale dans les pays en développement: du malthusianisme au féminisme? Lien social et Politiques 47.

Hardon, A. 2006. Contesting contraceptive innovation-Reinventing the script. Social Science \& Medicine 62: 614-627.

Hardon, A., and E. Moyer. 2014. Medical technologies: Flows, frictions and new socialities. Anthropology \& Medicine 21: 107-112.

Hartmann, B. 2016. Reproductive rights and wrongs: The global politics of population control. Haymarket Books.

Hendrixson, A. 2018. Population control in the troubled present: The ' 120 by 20 ' target and implant access program. Development and Change 0.

Hodgson, D., and S.C. Watkins. 1997. Feminists and Neo-Malthusians: Past and present alliances. Population and Development Review 23: 469-523.

Hunt, N.R. 1990. Domesticity and colonialism in Belgian Africa: Usumbura's foyer social, 1946-1960. Signs 15: 447-474.

Hunt, N.R. 1999. A Colonial Lexicon: Of birth ritual, medicalization, and mobility in the Congo. Durham, NC: Duke University Press.

ICG. 2003. Réfugiés et Déplacés au Burundi: Désamorcer la Bombe Foncière. Rapport Afrique $N^{\circ} 70$. Nairobi, Bruxelles: International Crisis Group (ICG).

Ingelaere, B., and D. Kohlhagen. 2012. Situating social imaginaries in transitional justice: The Bushingantahe in Burundi. International Journal of Transitional Justice 6: 40-59.

Kohlhagen, D. 2012. Land reform in Burundi: Waiting for change after twenty years of fruitless debate. Global Protection Cluster. 
Li, T.M. 2007. The will to improve: Governmentality, development, and the practice of politics. Durham: Duke University Press.

Lock, M., and V.-K. Nguyen. 2018. The right population. In An anthropology of biomedicine, ed. M. Lock, V.K. Nguyen, 2nd ed, 127-157. Oxford: Wiley-Blackwell.

Manirakiza, R. 2008. Population et développement au Burundi. Paris: L'Harmattan.

Meadows, D., and Club of Rome. 1982. The limits to growth: A report for the Club of Rome's project on the predicament of mankind. New York: Universe Books.

Ministère à la Présidence chargé de la Bonne Gouvernance et du Plan, Ministère de la Santé Publique et de la Lutte contre le Sida, Institut de Statistiques et d'Études Économiques du Burundi, et al. 2017. Troisième Enquête Démographique et de Santé. Bujumbura, Burundi: ISTEEBU, MSPLS, et ICF.

Ministère de l'Intérieur and Institute for Resource Development. 1988. Enquête Démographique et de Santé au Burundi 1987. Gitega, Burundi.

Murphy, M. 2010. Technology, governmentality, and population control. History and Technology 26: 69-76.

Nkurunziza, L. 2011. Divergences sur les méthodes contraceptives entre le PNSR et l'Église Catholique, IWACU, Bujumbura, Burundi. https://www.iwacu-burundi.org/.

Population Media Center. 2018. Agashi project. https://www.populationmedia.org/projects/agashi.

Potvin J. 2018. Biopolitics, risk, and reproductive justice: the Governing of Maternal Health in Canada's Muskoka Initiative. Graduate Program in Women's Studies and Feminist Research. Electronic Thesis and Dissertation Repository. 5956. https://ir.lib.uwo.ca/etd/5956 The University of Western Ontario.

Purdeková, A. 2017. Respacing for peace? Resistance to integration and the ontopolitics of rural planning in post-war Burundi. Development and Change 48: 534-566.

République du Burundi. 2011a. Plan national de développement sanitaire 2011-2015. Bujumbura: Ministère de la Santé Publique et de la Lutte contre le Sida du Burundi (MSPLS).

République du Burundi. 2011b. Vision Burundi 2025. Bujumbura: Ministry of Planning and Communal Development/Forecasting Unit United Nations Development Programme in Burundi.

République du Burundi. 2014. Les outils de mise en oeuvre du financement basé sur la performance à l'usage au niveau des formations sanitaires. Ministère de la Santé Publique et de la Lutte contre le Sida.

République du Burundi. 2016. Plan d'accélération de la planification familiale 2015-2020.

Richey, L.A. 2004. Construction, control and family planning in Tanzania: Some bodies the same and some bodies different. Feminist Review 56-79.

Schwarz, J., Dumbaugh, M., Bapolisi, W., et al. 2018. "So that's why I'm scared of these methods": Locating contraceptive side effects in embodied life circumstances in Burundi and eastern Democratic Republic of the Congo. Social Science \& Medicine 220: 264-272.

Serna, E. 2018. Faire et défaire la virilité. Les stérilisations masculines volontaires en Europe dans l'entredeux-guerres. Genève: Université de Genève, Faculté des Lettres et Université de Lille, IRHIS.

Sommers, M. 2013. Bas Horizons (Low Horizons) Adolescents et violence au Burundi. UNICEF-Burundi.

Takeshita, C. 2012. The global biopolitics of the IUD: How science constructs contraceptive users and women's bodies. Cambridge: PIT Press.

The World Bank and UNICEF. 2017. Delivering health services under fiscal stress: Burundi public expenditure review. Global practices: Governance and macroeconomics and fiscal management. The World Bank \& UNICEF Burundi.

Thibon C. 2004. Histoire démographique du Burundi: Karthala.

Thomas, L.M. 2003. Politics of the womb: Women, reproduction, and the state in Kenya. London: University of California Press.

Thomé, C. 2016. D'un objet d'hommes à une responsabilité de femmes. Entre sexualité, santé et genre, analyser la métamorphose du préservatif masculin. Sociétés Contemporaines 104: 67-94.

Uvin P. 2009 Life after violence. A People's Story of Burundi. 211.

van der Sijpt, E. 2014. Complexities and contingencies conceptualised: Towards a model of reproductive navigation. Sociology of Health \& Illness 36: 278-290.

van Leeuwen, M. 2010. Crisis or continuity?: Framing land disputes and local conflict resolution in Burundi. Land Use Policy 27: 753-762.

Vervisch, T.G., K. Vlassenroot, and J. Braeckman. 2013. Livelihoods, power, and food insecurity: Adaptation of social capital portfolios in protracted crises-case study Burundi. Disasters 37: 267-292.

Wilson, K. 2015. Towards a radical re-appropriation: Gender, development and Neoliberal Feminism. Development and Change 46: 803-832.

Wittig, K. 2017. "C'est comme ça que cela pourrait recommencer" : L'épineuse question foncière au Burundi. Canadian Journal of African Studies/revue Canadienne Des Études Africaines 51: 1-22.

World Food Program. 2008. Comprehensive food security \& vulnerability analysis, Burundi. Rome: WFP. 
Publisher's Note Springer Nature remains neutral with regard to jurisdictional claims in published maps and institutional affiliations. 